\title{
Characterization of decayed ceramic sculptures decorating the Pardon portico of Seville cathedral, Spain
}

\author{
J.L. Pérez-Rodríguez ${ }^{\mathrm{a}, *}$, C. Maqueda ${ }^{\mathrm{b}}$, A. Justo , E. Morillo $^{\mathrm{b}}$, \\ M.C. Jiménez de Haro \\ ${ }^{\mathrm{a}}$ Instituto de Ciencia de Materiales de Sevilla (C.S.I.C.-Univ. de Sevilla), Apdo. 1115, 41080 Sevilla, Spain \\ bInstituto de Recursos Naturales y Agrobiología(C.S.I.C.), Apdo. 1052, 41080 Sevilla, Spain
}

Received 10 November 1993; accepted after revision 27 April 1994

\begin{abstract}
The decay of the ceramic sculptures decorating the Pardon portico of Seville cathedral has been studied. The material of the corbels and canopies is alabaster. The presence of dolomite in some black veins initiates the high erosion of the material. The ceramics of the different sculptures show two groups of mineralogical composition: (a) quartz, gehlenite and wollastonite, and (b) illite, calcite and feldspars. The differences in colour of the sculptures are attributed to the firing temperature. The environment, the repair and fixing materials added to the sculptures, and interactions between the ceramic materials and the environment are responsible for the decay.
\end{abstract}

\section{Introduction}

The Cathedral of Seville (Spain) is considered one of the most important monuments of Christendom. It has various porticos decorated with terracotta sculptures. The sculptures of the Birth and Baptism porticos were made by Mercardante, and have been studied previously by Maqueda et al. (1985), Maqueda et al. (1991) and Pérez-Rodríguez et al. (1985) . A third portico, the Pardon, is decorated with terracotta sculptures of an anonymous artist.

The Pardon portico displays four ceramic statues which represent St. Peter, St. Paul, the Virgin and an Archangel. They are set on corbels and covered by canopies. In addition there is a high relief depicting the casting out of the money-changers.

\footnotetext{
*Correspondence to: Universidad de Sevilla, C.S.I.C. Institute of Materials Science, P.O. Box 1115, 41080 Sevilla, Spain.
} 
The ornamental ceramic industry has a long tradition in Seville, especially since the 15 th and 16 th century. The raw material used is blue marl from the Tertiary (Miocene), alone or mixed with other sandier materials from the Quaternary or the Paleozoic extracted from the Guadalquivir Valley near Seville.

González-García et al. (1988), González-García et al. (1990) have studied firing transformation of these materials. They found that the process involves the formation of calcium silicate and calcium aluminosilicates such as wollastonite, gehlenite, anorthite and other plagioclases. Abrate-Zohar et al. ( 1985) indicate that the presence/absence of illite and/ or crystobalite is a suitable criterium for knowing the firing temperature of terracotta ornaments.

The firing colour of clay materials is important in ornamental sculptures. There is a close relationship between the occurrence of high-temperature crystalline phases and the claybrick colour after firing under oxidizing conditions. The presence of goethite and hematite indicates oxidizing conditions (Abrate-Zohar et al., 1985). A red or red brown colour is attributed to the formation of dicalciumferrite and/or incorporation of iron in gehlenite or pyroxene when a high proportion of calcium carbonate is present (Kreimeyer, 1985; De la Torre-López et al., 1992). A knowledge of the mineralogical phases in ceramics helps to determine the materials and techniques used in making the sculptures. At the same time, the weathering and decay of ceramic sculptures set in the open air have become a problem of great interest. The retardation or suppression of these destructive processes requires a wealth of information about ceramic properties, the environment in which the sculptures are located, and the degree of alteration.

Binda et al. (1985) have studied the deterioration of porous materials (bricks) due to salt crystallization under different thermohygrometric conditions, and Binda et al. (1992) found that the effect of salt crystallization is a continuous delamination from the exterior surface. This fact is in agreement with the results obtained by Charola and Lewin (1983). Carlsson (1988) indicates that air pollutants such as $\mathrm{SO}_{2}$ and $\mathrm{NO}_{x}$ give acid water solutions that increase the deterioration.

Given the great artistic value and advanced state of deterioration of the sculptures of the Pardon portico, it was decided to carry out a scientific study prior to their restoration. The study comprised three parts. The first was the characterization of mineralogical phases of the original ceramic, in order to know its composition and to establish the manufacturing techniques (materials used, firing temperature, etc.). The second was to study the products deposited or formed on the sculptures to determine the decay process. The third was the characterization and decay of the corbels and canopies (non-ceramic materials).

\section{Experimental}

\subsection{Materials}

Samples were taken from the different sculptures and a high relief. The samples included ceramics, alteration crusts, repair materials, and deposited products. Samples were also taken from corbels and canopies. 


\subsection{Techniques}

The samples were treated by the three-acid method of Bennet et al. (1962). The extracts were used to determine iron, aluminium, titanium, lead, magnesium and calcium by atomic absorption spectrometry, and sodium and potassium by emission spectrophotometry. Silicon was determined according to Maqueda et al. (1986).

The carbon content was obtained by oxidation of organic matter with potassium dichromate.

The sulphur content was determined in a LECO set, model 552, by formation of $\mathrm{SO}_{2}$ in an induction furnace and subsequent titration by the iodometric method.

Total nitrogen was determined by the Kjeldahl method. The nitrogen from nitrates and nitrites was determined by fixation with salicylic acid and reduction with sodium thiosulphate followed by titration in a Kjeldahl apparatus (Nehring, 1960).

Phosphorous was determined by the method of Murphy and Riley (1962). $\mathrm{SO}_{2}, \mathrm{NO}_{2}$ and $\mathrm{CO}$ were determined with a portable fine gas analyser Lancom, model 6500 . The temperature and relative humidity were obtained by the appropriate sensors attached to a data log.

The crystalline phases were characterized by X-ray diffraction (XRD) using a Siemens diffractometer, model Kristalloflex D-500.

Scanning electron micrographs were obtained with an ISI SS40 apparatus equipped with a Kevex $8000 \mathrm{X}$-ray dispersive energy analyzer (EDAX).

Differential thermal analysis (DTA) was carried out using a Setaram apparatus model $92,16-18$, operating at a heating rate of $10^{\circ} \mathrm{C} / \mathrm{min}$.

The infrared absorption spectra (IR) were recorded from $4800 \mathrm{~cm}^{-1}$ to $250 \mathrm{~cm}^{-1}$ using a Nicolet 510P FT-IR spectrophotometer. The samples were prepared with $\mathrm{KBr}$.

\section{Results and discussion}

\subsection{Corbels and canopies}

Samples were taken from the corbels and canopies after removing a large amount of dust covering them. The XRD patterns of some of these samples (Fig. 1a) showed that they were constituted of calcium sulphate dihydrate. Their study by EDAX showed the presence of $\mathrm{S}$ and $\mathrm{Ca}$ (Fig. 2). These results indicate that the material of the corbels and canopies is alabaster, whose morphology was confirmed by electron microscopy (Fig. 3).

The chemical composition of alabaster leads to alteration when exposed to atmospheric polluting agents, but the quality of the alabaster plays an important role in the decay process. Detailed study of the samples showed that there were some cracks and black veins in the alabaster.

In order to know the decay process of the alabaster, samples from the black veins and the powdery material located inside the cracks were studied. The XRD patterns showed that the dark veins were constituted of alabaster and magnesium calcium carbonate (dolomite). The powdery material contained a high proportion of dolomite and a small amount of calcium sulphate dihydrate (Fig. 1c). 


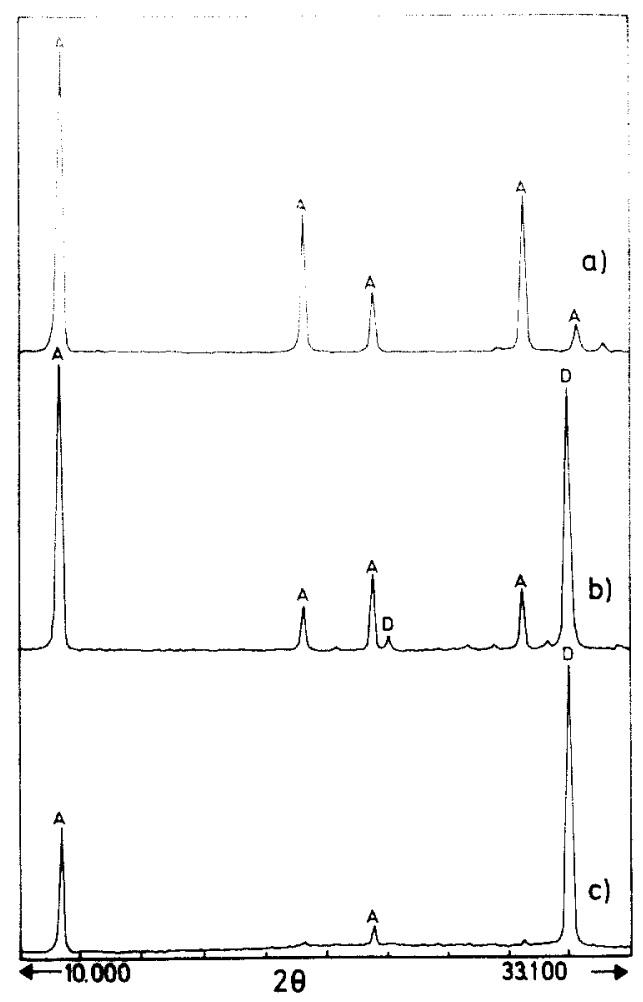

$A=$ Alabaster,$D=$ Dolomite

Fig. 1. XRD patterns of the materials of the corbels and canopies: (a) alabaster, (b) samples from the black veins, (c) powdery material located inside the cracks.

Dolomite produces hydrated magnesium sulphate and calcium sulphate by reaction with the $\mathrm{SO}_{2}$ from the polluted air. The change of volume produced by this chemical transformation and the high solubility of the magnesium sulphate, that can be removed in the rain

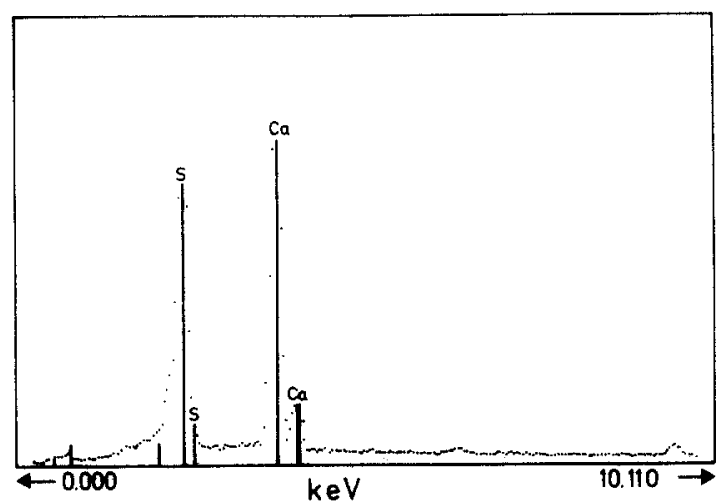

Fig. 2. Chemical analysis by EDAX of the samples from the corbels and canopies. 


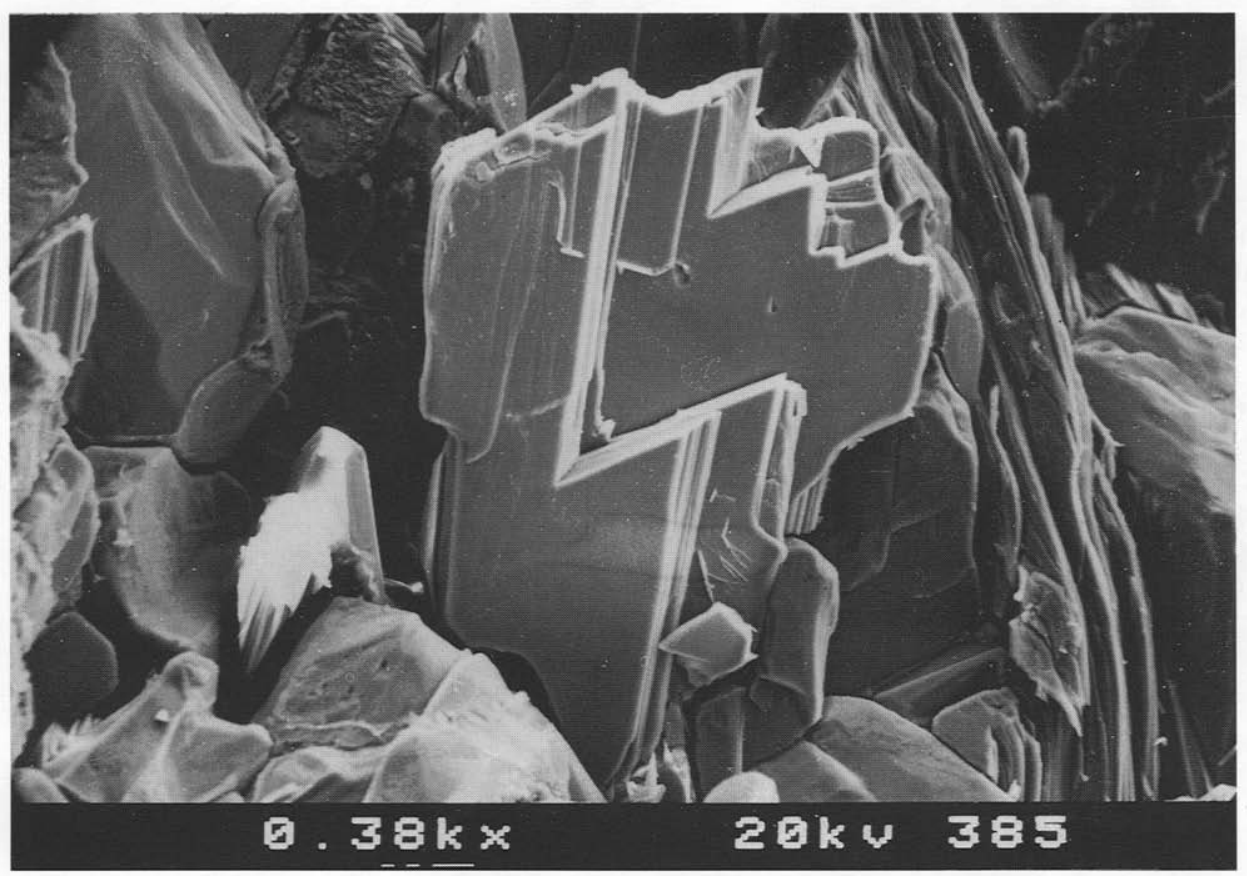

Fig. 3. Morphology of the material of the corbels and canopies. The longer scale marker $=10 \mu \mathrm{m}$.

water, are mainly responsible for the high desintegration of this material. Epsomite $\left(\mathrm{MgSO}_{4} \cdot 7 \mathrm{H}_{2} \mathrm{O}\right)$ and calcium sulphate dihydrate were characterized by XRD.

\subsection{Ceramics}

\section{St. Paul and St. Peter sculptures}

Chemical analysis of the ceramic material of St. Paul (Table 1) showed a high percentage of silicon, followed by calcium and aluminium and small amounts of magnesium, iron and potassium. This material has an apparent density of $1.63 \mathrm{~g} / \mathrm{cm}^{3}$, open porosity of $38.3 \%$ and a specific surface of $12 \mathrm{~m}^{2} / \mathrm{g}$.

Chemical analysis of the ceramic material of St. Peter gives results that are very similar to those of St. Paul. However, the mineralogical composition of the two sculptures is quite different. The X-ray diffraction patterns of ceramic samples from St. Paul showed the presence of quartz, gehlenite and wollastonite (Fig. 4a). The ceramic samples from St. Peter consisted of illite, calcite and feldspars (Fig. 4b). The difference between the groups is that in the first, illite and calcite were not present. Various studies exist on ceramic materials that, like those studied in this paper, are rich in $\mathrm{CaO}, \mathrm{SiO}_{2}$ and $\mathrm{Al}_{2} \mathrm{O}_{3}$. They show that different phases are formed during the firing and that illite disappears at $850^{\circ} \mathrm{C}$. This could be explained by the statement of melting as far as the first melt in illitic clays is formed from $800^{\circ} \mathrm{C}$. González-García et al. (1988) have shown in ceramic materials similar to those used to make these sculptures that there is a partial formation of glass structure at $800^{\circ} \mathrm{C}$. The XRD diagrams shown by these authors present weak diffraction of illite after 
Table 1

Chemical analysis of ceramic samples (\%)

\begin{tabular}{lrr}
\hline & $\begin{array}{c}\text { St. } \\
\text { Paul }\end{array}$ & $\begin{array}{l}\text { St. } \\
\text { Peter }\end{array}$ \\
\hline $\mathrm{SiO}_{2}$ & 52.73 & 51.80 \\
$\mathrm{Al}_{2} \mathrm{O}_{3}$ & 12.60 & 12.03 \\
$\mathrm{Fe}_{2} \mathrm{O}_{3}$ & 5.88 & 5.48 \\
$\mathrm{TiO}_{2}$ & 0.80 & 0.75 \\
$\mathrm{CaO}$ & 12.36 & 13.50 \\
$\mathrm{MgO}$ & 2.27 & 2.05 \\
$\mathrm{Na} O$ & 1.10 & 1.02 \\
$\mathrm{~K}_{2} \mathrm{O}$ & 2.36 & 2.22 \\
$\mathrm{MnO}$ & 0.07 & 0.07 \\
$\mathrm{SO}$ & 2.70 & 2.55 \\
Loss on ignition & 6.85 & 8.37 \\
\hline
\end{tabular}

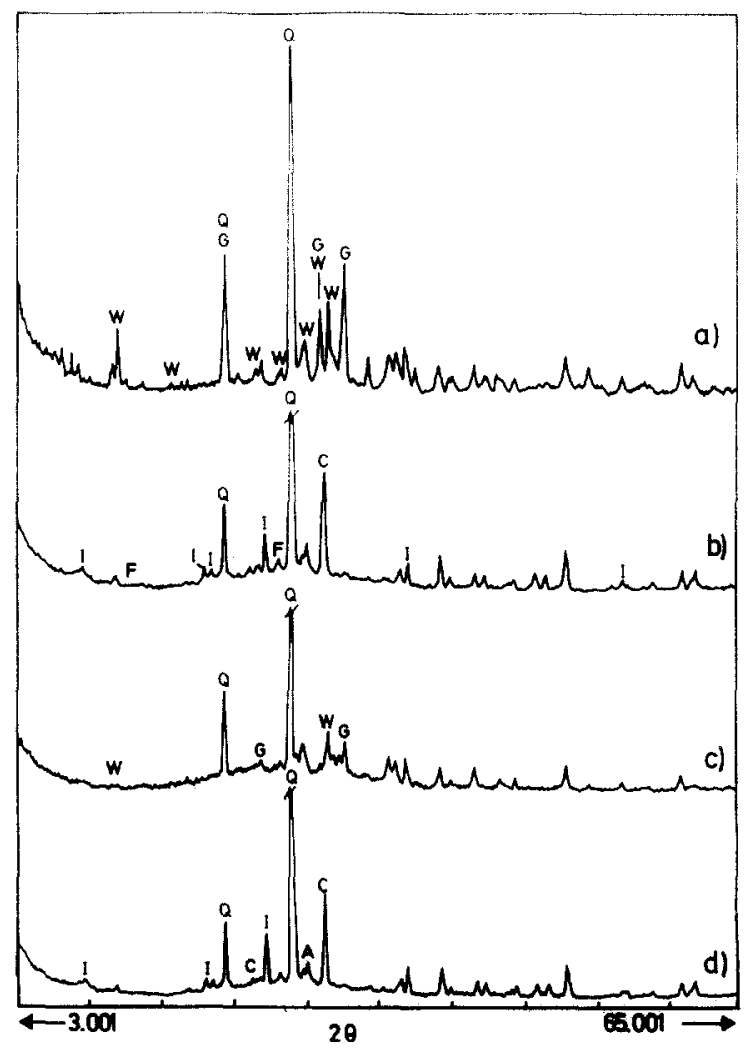

Fig. 4. XRD patterns of the ceramics: (a) St. Paul, (b) St. Peter, (c) Virgin and archangel, (d) high relief. Key: $\mathrm{Q}=$ quartz, $\mathrm{G}=$ gehlenite, $\mathrm{W}=$ wollastonite $\mathrm{I}=$ illite, $\mathrm{F}=$ feldspar, $\mathrm{C}=$ calcite, $\mathrm{A}=$ anorthite. 
heating at $900^{\circ} \mathrm{C}$, which disappears at higher temperatures. According to these results, the group of ceramics in which illite was absent and gehlenite and wollastonite were present was fired at a temperature over $900^{\circ} \mathrm{C}$, and the other group below $900^{\circ} \mathrm{C}$.

The calcium carbonate in the samples may have various origins. One of these is primary calcite that had not reacted with the other components during the ceramic manufacture. The presence of some white nodules, composed of calcium carbonate, indicates that, by firing at temperatures between 500 and $800^{\circ} \mathrm{C}$, the $\mathrm{CaO}$ formed lumps which afterwards were carbonated.

Fabbri (1992) shows that calcite in the ceramic pieces of S. Cristina church in Bolsena is a secondary product due to recarbonation of unreacted calcium oxide which remain after firing due to the very high calcite content of the raw materials.

\section{Archangel and Virgin sculptures}

The study of these sculptures was carried out separately to those of St. Peter and St. Paul sculptures because they are considered stylistically different.

Samples of these sculptures had similar chemical composition, physical properties and mineralogical phases (Fig. 4c). Their XRD patterns showed that they consisted of wollastonite, gehlenite and quartz, and that calcite was not present. This mineralogical composition indicates that these sculptures were fired at a temperature over $900^{\circ} \mathrm{C}$.

\section{High relief}

The composition and physical properties of the ceramic samples taken from the high relief were similar to those of the sculptures. Ceramic material consisting of calcite, quartz, anorthite and illite (Fig. 4d). Sometimes wollastonite and gehlenite were present, especially in samples from the surface. In these figures the firing gradient from the external part to the internal part is remarkable.

\section{Repair or restoration materials}

Different materials have been used in the past for restoration. Some of these were ceramic materials consisting of calcite, quartz and illite (Fig. 5c). The calcite crystals are very abundant and easily observable by electron microscopy. All these repair materials show a higher degree of alteration than the original ceramics. Obviously, repair materials are less durable due to underfiring.

There are other repair materials constituted of calcite and vaterite as shown in Fig. 5b. Vaterite formation requires the presence of barium. It is not readily found in nature and is little used in restoration, although it has been found in lead pipes from the Roman period. Some cracks have been filled with gypsum (Fig. 5a) and cement. Portland cement, morter cement and many braces have also been found.

The internal surface of the St. Paul sculpture is covered with a layer of several millimetres consisting of gypsum, anhydrite and quartz.

Gypsum, Portland cement and carbonates and the braces are very detrimental to the sculptures because they are largely responsible for the decay process, by acidity effect, salt movement, change of volume, etc. These processes will be discussed later. 


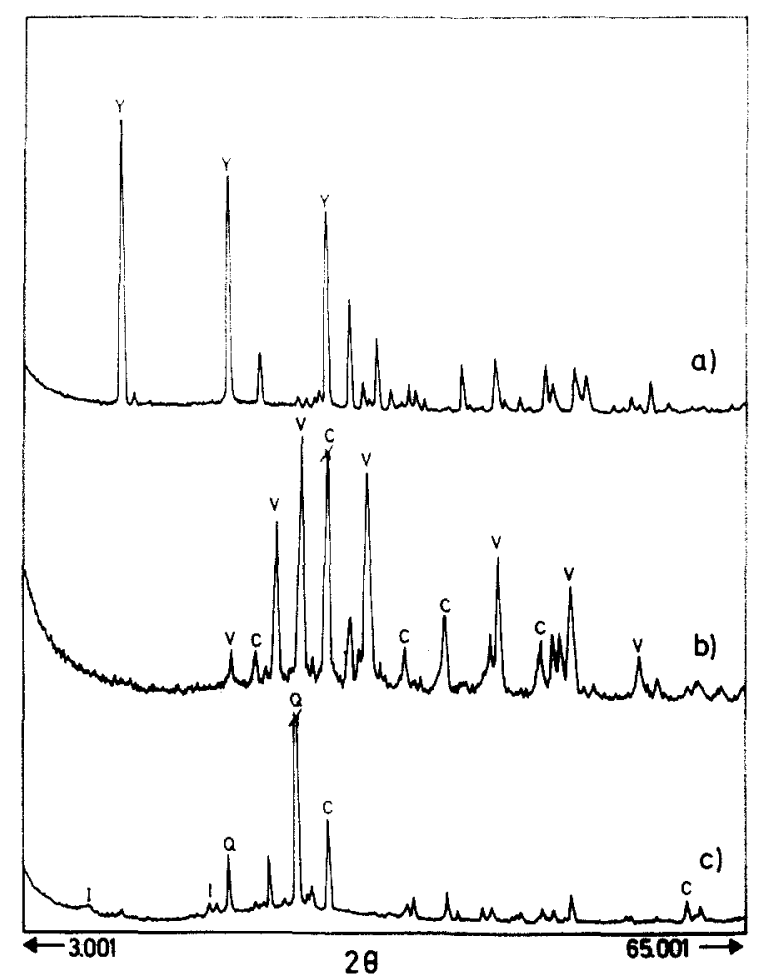

Fig. 5. XRD patterns of the repair materials. Key: $Y=$ gypsum, $V=$ vaterite, $C=$ calcite, $I=$ illite, $Q=$ quartz.

\section{Study of surface deposits}

From the point of view of alteration, the study of the materials deposited or formed on the sculptures is of great importance in obtaining a better understanding of the nature of the alteration.

The surface of the statues is covered by dust. Chemical analysis of this dust showed a high content of carbon $(4.54 \%)$, nitrogen $(0.55 \%)$, lead $(0.32 \%)$, phosphorus $(0.45 \%)$ and sulphur $(0.78 \%)$ coming from environmental pollution. The study by mass spectrometry (Fig. 6) showed a high proportion of alkanes produced by petrol combustion, the same source as for lead. The Seville cathedral is in a high traffic density zone.

Electron microscopy showed large amounts of gypsum (platy and euhedral crystals). Gypsum is present in both the internal and external parts of the sculptures. There is a high biological activity: fungal hyphae, bacteria and animal residues.

In some altered parts, the surface deposits mixed with the remains of the ceramic form a hard crust. Sometimes this falls off and the ceramic presents an almost sandy appearance due to its high degree of alteration.

The study of these materials by electron microscopy, chemical analysis and XRD showed the presence of illite, quartz and carbonate. A high biological activity was also shown (Fig. 7). The results of the mass spectrometry study (Fig. 6) were similar to those of the dust from of the sculptures, showing the presence of alkanes. 


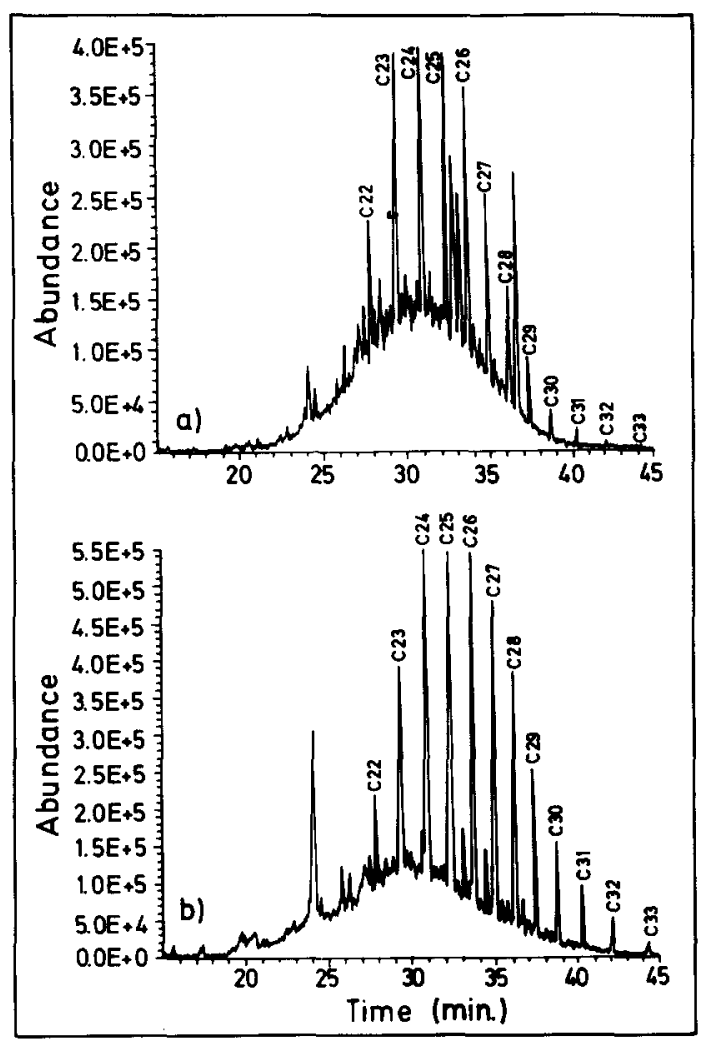

Fig. 6. Mass spectra of: (a) dust, (b) crust.

The interaction of atmospheric sulphuric pollutants with the calcium oxide of the ceramic produces gypsum. As this mineral is detected in high concentration, part of it may be due to the surrounding carbonatic stones, solution of the bonding mortar and airborne particles. The particle content was $250 \mu \mathrm{g} / \mathrm{m}^{3}$ (constituted mainly by gypsum, calcite, $\mathrm{Pb}, \mathrm{Cr}, \mathrm{Mn}$, $\mathrm{V}$ ). The material of the sculptures is a porous medium where the gypsum crystals precipitate inside the pores or fissures. The stresses due to the gypsum generate micro-cracks. A similar phenomenon has been observed in the Carthusian Monastery of Pavia (Abrate-Zohar et al., 1985). The acidity is due to $\mathrm{CO}, \mathrm{SO}_{x}, \mathrm{NO}_{x}$, coming from the repair materials, animal residues, and from the polluted air (the polluted air contains $\mathrm{SO}_{2}=62 \mu \mathrm{g} / \mathrm{m}^{3}, \mathrm{NO}_{2}=98$ $\mu \mathrm{g} / \mathrm{m}^{3}, \mathrm{CO}=3.7 \mathrm{mg} / \mathrm{m}^{3}$ ). These chemical compounds react with different components of the sculptures. Soluble salts such as gypsum could be transported to the surface during wetting and drying conditions, producing efflorescence. This effect can cause damage after recrystallization (Carlsson, 1988), and also produce delamination of the surface, as reported by several of the authors mentioned before. The temperature in the sculptures reaches about $50^{\circ} \mathrm{C}$ in summer which falls to $0^{\circ} \mathrm{C}$ in winter; the relative humidity changes from 80 to $36 \%$. These values play an important role in dehydration and salt movement, solution, etc. Oxidation of metals can also produce pernicious effects by expansion, etc. 


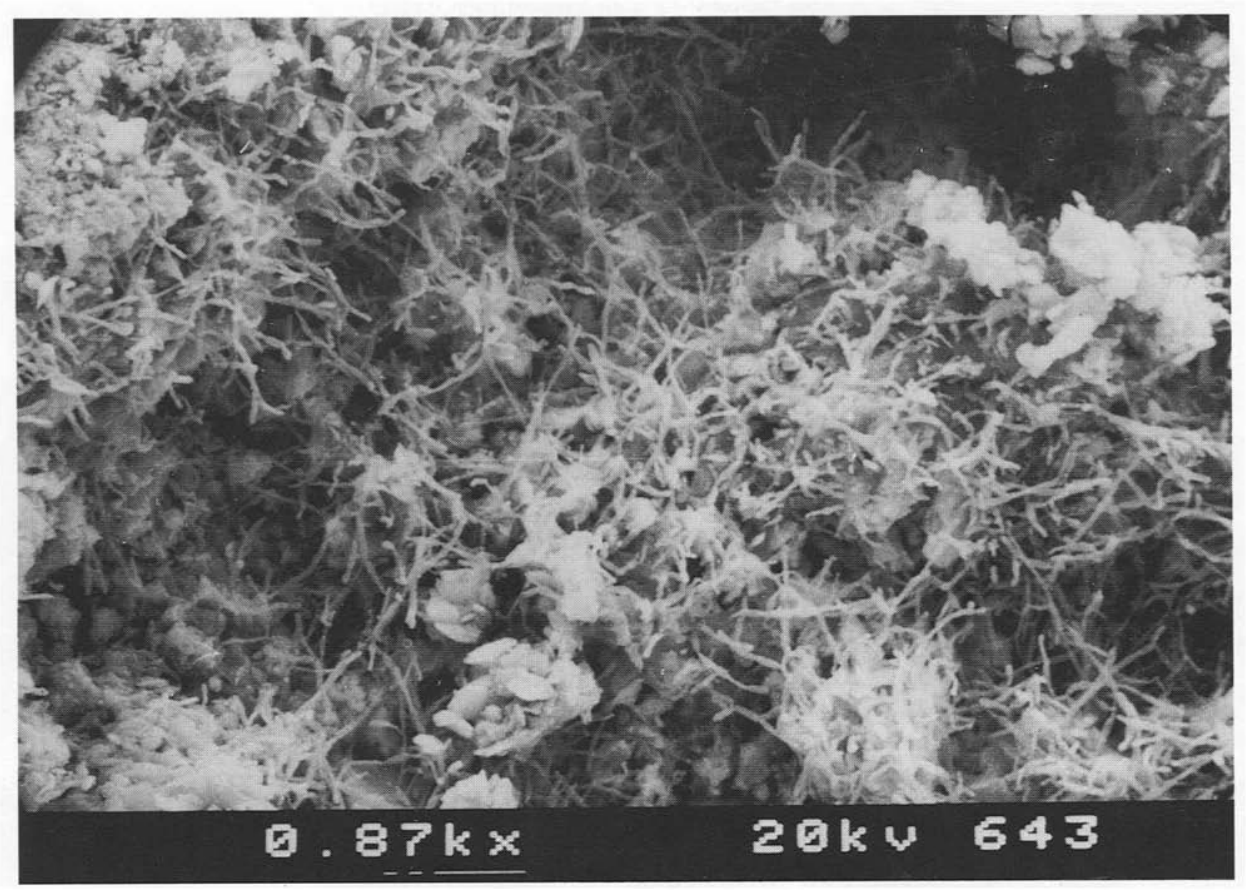

Fig. 7. Electron micrograph showing biological activity. The longer scale marker $=10 \mu \mathrm{m}$.

\section{Colours of St. Peter and St. Paul sculptures}

According to the Munsell colour scale, St. Peter sculpture has a light red colour (2.5YR $6 / 8$ ) and St. Paul a light yellow colour (2.5Y 7/4). The difference of colour was not important at manufacturing time as the sculptures were polychromed. Today the polychromy has disappeared and the figures show different colours. It is interesting to know the cause of the difference.

The XRD study showed the presence of different mineralogical phases in the two sculptures. St. Peter samples (red colour) are constituted of calcite, quartz, anorthite and illite, and St. Paul samples (light yellow colour) of gehlenite, wollastonite, quartz and anorthite. Calcite sometimes appears in a small amount. In some parts of the St. Paul sculpture the colour is intermediate from light red to light yellow and the mineralogical composition is also intermediate.

The DTA curves of representative samples of St. Peter and St. Paul sculptures are shown in Fig. 8. Both samples showed an endothermic effect at $95^{\circ} \mathrm{C}$ and $140^{\circ} \mathrm{C}$ corresponding to a weight loss from adsorbed water and water of hydration (from gypsum), respectively. The gypsum is the result of pollution as indicated before. An exothermic effects appeared at about $350^{\circ} \mathrm{C}$ due to organic matter from the environment or to ferric oxide gels (Mackenzie and Berggren, 1970) from the ceramic alteration. The sample from St. Peter showed two endothermic effects at $573^{\circ} \mathrm{C}$ and $760^{\circ} \mathrm{C}$ due to $\alpha \rightarrow B$ quartz transformation and decomposition of calcium carbonate, respectively. The exothermic effect at $900^{\circ} \mathrm{C}$ due to the formation of new phases (wollastonite and gehlenite) was present only in the St. Peter 


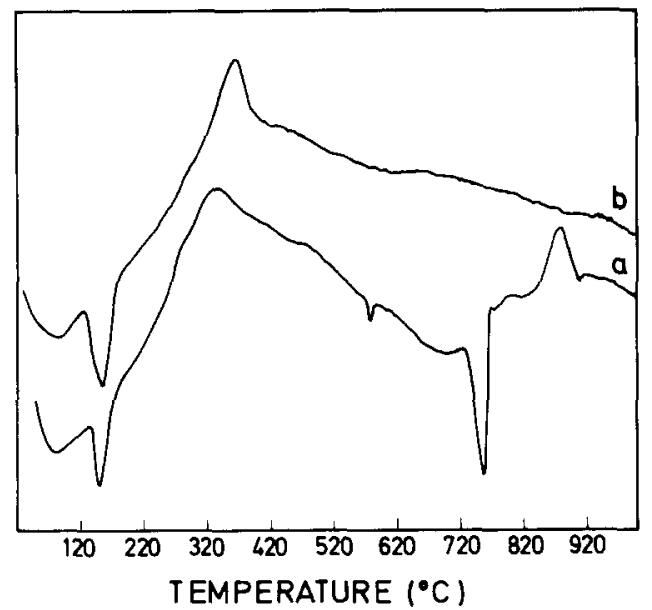

Fig. 8. DTA curves of the samples of (a) St. Peter, (b) St. Paul.

sample. The XRD confirmed the presence of wollastonite and gehlenite (which were not present at the beginning) after heating at that temperature. The DTA curve of the sample from St. Paul (light yellow) did not show endothermic or exothermic effects above $420^{\circ} \mathrm{C}$, since the sculpture was originally fired above $900^{\circ} \mathrm{C}$.

Cracks in the St. Peter sculpture (and especially in the high relief), show a reddish colour in the internal parts, indicating the different temperature gradient during the firing. The results of the XRD study and thermal analysis are in agreement with a lower temperature of firing.

The scanning electron microscopy shows in the light red coloured ceramic initial vitrification, phyllosilicate laminae being distinguished, whereas in the light yellow coloured ceramic the vitrification is much higher and the phyllosilicate laminae are not preserved. Similar results have been shown by different authors (Tite and Maniatis, 1975; Freestone and Middleton, 1987; Nuñez et al., 1992).

In order to check the effect of firing temperature on the ceramics, a series of ceramic briquettes (with similar characteristics to the sculptures), was made and fired in artisan furnaces similar to those used for centuries in the local ceramic industry. The ceramic briquettes displayed different colours after firing due to the effect of the temperature.

The XRD diagrams of the red samples show calcite, quartz, illite and iron oxides (hematites). These phases disappear when the colour is more yellow, and wollastonite, gehlenite and quartz appear. The changes in colour correspond with the mineralogical phases present and are the same as appear in the sculptures.

The sculpture sample which has a more reddish colour shows an IR spectra with absorption bands corresponding to $-\mathrm{CH}_{2}$ and $-\mathrm{CH}_{3}$, suggesting the presence of organic compounds that could also be responsible for its colour (Fig. 9). In order to check this, the sample was heated above the temperature of the exothermic effect. The colour remained, and thus is not attributable to the addition of an organic compound or moisture.

Electron microscopy and chemical analysis by EDAX showed that the colour was not produced by inorganic compounds or different particle size. 


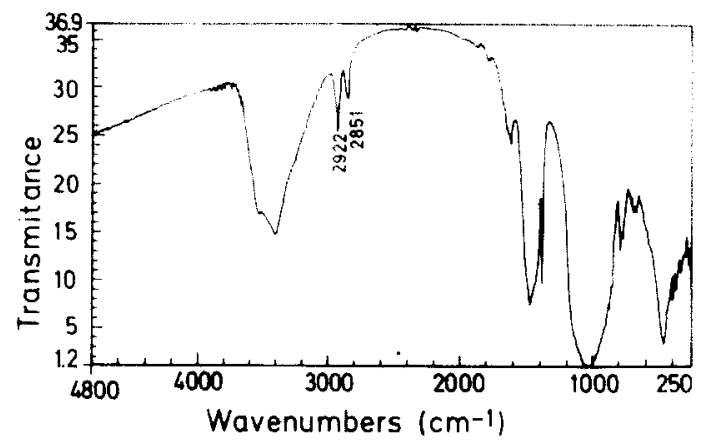

Fig. 9. IR spectra of samples of St. Peter.

\section{Conclusions}

The investigation revealed that the corbels and canopies are made of alabaster. The presence of veins (constituted of dolomite) facilitates its degradation in the open air, due to the formation of the more highly soluble magnesium sulphate.

Different ceramic repair materials fired at a lower temperature than the sculptures have been used. They are less durable due to underfiring. Other additives such us gypsum, vaterite, calcite, cements and fixing iron materials are also present.

The data confirm that the material used to make the sculptures is very similar to the materials typically used in the ceramic industry of Seville. The sculptures of St. Paul, the Archangel and the Virgin have been fired above, and St. Peter below, $900^{\circ} \mathrm{C}$.

The differences between the colour of St. Peter and those of the other sculptures are attributed to the firing temperature. The lower temperature permits the iron oxides to be free, giving a reddish colour. The temperature gradient also affects the colour of the sculptures.

Environmental pollution, effect of restoration materials, and reactions between the ceramic materials and polluting gases have resulted in calcium sulphate dihydrate, calcium carbonate, alkanes from petrol combustion, animal residues, fungi, bacteria, iron, lead (from the polychrome and petrol combustion), Portland cements, chloride and nitrate collecting and forming in the figures. All these materials are largely responsible for the decay process.

\section{Acknowledgements}

This work was made possible through financial support from CEC under project STEPCT90-01001 and the Direccion de Bienes Culturales de la Consejeria de Cultura y Medio Ambiente de la Junta de Andalucía.

\section{References}

Abrate-Zohar, M.A., Zezza, V., Veniale, F. and Setti, M., 1985. Decay stage and causes of the terracotta ornaments (cloister of the Carthusian monastery, Pavia-Italy). Proc. 5th Int. Cong. on Deterioration and Conservation of Stone, Lausanne, Suisse, pp. 443-451. 
Bennet, H., Eardley, R.P., Hawley, W.G. and Thwaites, I., 1962. Routine control analysis of high-silica and aluminosilicate materials. Trans. Br. Ceram. Soc., 61: 636-666.

Binda, L., Baronio, G. and Charola, A.E., 1985. Deterioration of porous materials due to salt crystallization under different thermogravimetric conditions. I. Brick. Proc. 5th Int. Cong. on Deterioration and Conservation of Stone, Laussanne, Suisse, pp. 279-288.

Binda, L., Baronio, G. and Squarcine, 1992. Evaluation of the durability of bricks and stones and of preservation treatments. In: J. Delgado Rodríguez, F. Henriques and F. Telmo (Editors), Proc. 7th Int. Congr. on Deterioration and Conservation of Stone, Lisbon, Portugal, pp. 753-761.

Carlsson, R., 1988. Mechanisms of deterioration in ceramics and glass. Durability of Building Materials, 5: 421427.

Charola, A.E. and Lewin, S.L., 1983. Examples of stone decay due to salt efflorescences. Proc. 3rd Int. Cong. on Deterioration and Preservation of Stone, Venice, Italy, pp. 153-163.

De la Torre López, M.J., Rodríguez Gordillo, J. and Sebastian Pardo, E., 1992. Mineralogical and chemical characteristics of bricks from some archaeological sites in the Alhambra, Granada (Spain). Miner. Petrog. Acta, XXXVA: 171-179.

Fabbri, B., 1992. About the clay used for the majolica altar of S. Cristina church in Bolsena (Central Italy). Miner. Petrog. Acta, XXXVA: 161-170.

Freestone, I.C. and Middleton, A.P., 1987. Mineralogical application of the analytical SEM in archaeology. Miner. Mag., 51: 21-31.

González-García, F., García-Ramos, G., Romero Acosta, V. and González Rodríguez, M., 1988. Arcillas empleadas en la fabricación del azulejo artístico de Sevilla. Propiedades y transformaciones por cocción. I. Materiales que contienen carbonato de calcio. Bol. Soc. Esp. Ceram. Vidr., 7: 215-223.

González-García, F., Romero Acosta, V., García-Ramos, G. and González-Rodríguez, M., 1990. Firing transformations of mixtures of clays containing illite, kaolinite and calcium carbonate used by ornamental tile industries. Appl. Clay Sci., 5: 361-375.

Kreimeyer, R., 1985. Some notes on the firing colour of clay bricks. Appl. Clay Sci., 2: 175-183.

Mackenzie, R.C. and Berggren, G., 1970. Oxides and hydroxides of higher valency elements. In: R.C. Mackenzie (Editor), Differential Thermal Analysis. Academic Press, London, pp. 271-302.

Maqueda, C., Pérez-Rodríguez, J.L. and Justo, A., 1985. Degradation of ceramic sculptures on the Cathedral of Seville. Miner. Petrogr. Acta, 29A: 591-598.

Maqueda, C., Pérez-Rodríguez, J.L. and Justo, A., 1986. Problems in the dissolution of silicates by acid mixtures. Analyst, 111: 1107-1108.

Maqueda, C., Pérez-Rodríguez, J.L. and Justo, A., 1991. Decay process of the terracotta ornaments in three of the porticos of Seville cathedral. In: M.C. Ganorkar and N. Rama Rao (Editors), Proc. 1st Int. Colloquium on Role of Chemistry in Archaeology, Hyderabad, India, pp. 27-40.

Murphy, J. and Riley, J.P., 1962. A modified single solution method for the determination of phosphate in natural water. Anal. Chim. Acta, 27: 31-36.

Nehring, K., 1960. Agrikulturchemische Untersuchungs-methoden für Dünge und Futtermittel, Böoden und Milch: Bestimmung des Gesamtstikstoffs, Methode van O. Foerster. Verlag Paul Parey, Hamburg.

Nuñez, R., Delgado, A. and Delgado, R., 1992. The sintering of calcareous illitic ceramic. Application in archaeological research. In: A. López-Galindo and M.I. Rodríguez-García (Editors), Electron Microscopy'92, Vol. 2 (Proc. 10th European Congr. on Electron Microscopy, Granada, Spain).

Pérez-Rodríguez, J.L., Maqueda, C. and Justo, A., 1985. A scientific study of the terracotta sculptures from the porticos of Seville Cathedral. Stud. in Conservation, 30: 31-38.

Tite, M.S. and Maniatis, Y., 1975. Examination of ancient pottery using the scanning electron microscope. Nature, 257: $122-123$. 